\title{
THE EFFECTS OF ICI 33828 AND PROGESTERONE ON OESTROGEN-MAINTAINED CORPORA LUTEA IN THE SOW
}

\author{
D. L. GARBERS AND N. L. FIRST \\ Department of Meat and Animal Science, University of Wisconsin, Madison
}

(Received 24th October 1968)

Exogenous oestrogens maintain the corpora lutea (CL) in the cycling gilt (Gardner, First \& Casida, 1963). The pituitary is required, since oestrogen will not maintain $\mathrm{CL}$ in the gilt in which the pituitary stalk has been transected (Anderson, Dyck, Mori, Henricks \& Melampy, 1967). Oestrogen blocks pituitary LH and FSH release, and Rothchild (1966) has therefore suggested that increased prolactin release due to oestrogen may maintain the corpora lutea in the intact gilt. Prolactin, however, will not delay cL regression in the hypophysectomized pig (Du Buisson, Leglise, Anderson \& Rombauts, 1964). Since a single oestrogen injection was found to maintain CL in the sow (Nishikawa, 1959), oestrogen may stimulate a single release of a pituitary luteotrophin, induce a constant pituitary release of a luteotrophin, or act directly at the ovarian or uterine levels to effect the maintenance of the GL. Piper \& Foote (1968) suggested that both an initial release of pituitary LH due to oestrogen and an increased prolactin release may be involved in cL maintenance in the ewe. Hammond \& Robson (1951) demonstrated a direct effect of oestrogen on CL maintenance in the rabbit.

Wagner \& Veenhuizen (1965) reported that six gilts which received $25 \mathrm{mg}$ diethylstilboestrol (DES)/day starting at mid-cycle for 10 days, showed regression of CL by 1 day after treatment with 6 -chloro- $\Delta^{6}$-17-acetoxyprogesterone (GAP). GAP treatment was started on the day following the last DES treatment. These data indicate a possibility of progestagens being capable of overcoming the luteotrophic effect of oestrogens, although treatment with CAP during continued DES would have been more conclusive. Polge \& Day (1969) have indicated that PMSG can cause ovulation in gilts receiving ICI 33828, whereas Brinkley, Norton \& Nalbandov (1964) reported that PMSG does not normally cause ovulation in progestagen-blocked gilts. It is difficult to interpret these two reports since the PMSG industrial source was different. Garbers \& First (1969a) reported that both progesterone and ICI 33828 block pituitary LH and FSH release late in the pig oestrous cycle. A further experiment (Garbers \& First, 1969b) supported the hypothesis that ICI 33828 blocked LH release, since pigs showed oestrus but were blocked from ovulating by the ICI 33828 drug.

Because both progesterone and ICI 33828 appear capable of blocking pituitary FSH and LH release in the pig, and since the luteotrophic action of 
oestrogen is not understood, it was decided to undertake this study to determine if ICI 33828 or progesterone could cause regression of CL maintained by oestrogen.

Twenty-four primiparous sows were assigned randomly to treatment on the lst day of oestrus (Day 1). The treatments began on Day 10 and consisted of $7.5 \mathrm{mg}$ oestradiol- $17 \beta$ from Days 10 to 29 or 10 to 35 and 25,100 , or $200 \mathrm{mg} /$ day of ICI 33828 , or $150 \mathrm{mg} /$ day of progesterone, or $1000 \mathrm{mg} /$ day of medroxyprogesterone acetate from Days 20 to 29 or 20 to 35. The oestrogen and 150-mg progesterone doses were given in a $95 \%$ corn oil ; $2.5 \%$ ether; $2.5 \%$ isopropyl alcohol carrier injected subcutaneously in the flank or behind the shoulder. All sows received $1.8 \mathrm{~kg}$ of feed/day. ICI 33828 and medroxyprogesterone

TABLE 1

OVARIAN MEANS FOR SOWS TREATED WITH ICI 33828 OR PROGESTERONE DURING OESTROGEN TREATMENT TO MAINTAIN CORPORA LUTEA

\begin{tabular}{|c|c|c|c|c|c|c|c|}
\hline & $\begin{array}{c}\text { No. of } \\
\text { gilts }\end{array}$ & $\begin{array}{l}\text { Ovarian } \\
\text { wt }(g)\end{array}$ & $\begin{array}{c}\text { Total } C L \\
\text { wt }(g)\end{array}$ & No. $C L$ & $\begin{array}{l}\text { Stromal } \\
\text { wt }(g)\end{array}$ & $\begin{array}{l}\text { Mean } C L \\
w t(m g)\end{array}$ & $\begin{array}{c}\text { Ave. } C L \\
\text { dia. }(m m)\end{array}$ \\
\hline $\begin{array}{l}\text { Day } 30 \\
\text { Oestrogen* } \\
O+I_{25} \\
O+I_{100} \\
O+I_{200} \\
O+P_{150} \\
O+P_{1000}\end{array}$ & $\begin{array}{l}3 \\
2 \\
2 \\
2 \\
2 \\
2\end{array}$ & $\begin{array}{r}12 \cdot 3 \\
15 \cdot 9 \\
13 \cdot 8 \\
8 \cdot 8 \\
11.6 \\
8 \cdot 4\end{array}$ & $\begin{array}{l}5 \cdot 9 \\
5 \cdot 8 \\
6 \cdot 3 \\
4 \cdot 7 \\
3 \cdot 9 \\
2 \cdot 1\end{array}$ & $\begin{array}{r}15 \cdot 3 \\
20 \cdot 5 \\
20 \cdot 0 \\
12 \cdot 5 \\
12 \cdot 5 \\
8 \cdot 5\end{array}$ & $\begin{array}{l}5 \cdot 2 \\
8 \cdot 1 \\
5 \cdot 9 \\
3 \cdot 3 \\
6 \cdot 2 \\
5 \cdot 3\end{array}$ & $\begin{array}{l}388 \\
280 \\
321 \\
374 \\
282 \\
177\end{array}$ & $\begin{array}{l}8 \cdot 2 \\
7 \cdot 0 \\
8 \cdot 0 \\
8 \cdot 7 \\
7 \cdot 9 \\
5 \cdot 3\end{array}$ \\
\hline $\begin{array}{l}\text { Day } 36 \\
\text { Oestrogen } \\
O+I_{25} \\
O+I_{100} \\
O+I_{200} \\
O+P_{150} \\
O+P_{1000}\end{array}$ & $\begin{array}{l}1 \\
1 \\
2 \\
2 \\
3 \\
2\end{array}$ & $\begin{array}{r}15.2 \\
10.9 \\
11.0 \\
12.4 \\
8.4 \\
6.1\end{array}$ & $\begin{array}{l}6.5 \\
5.3 \\
4.7 \\
4.2 \\
3.2 \\
2.0\end{array}$ & $\begin{array}{r}18.0 \\
16.0 \\
15.0 \\
8.7 \\
13.3 \\
11.5\end{array}$ & $\begin{array}{l}7.2 \\
4.6 \\
5.4 \\
2.8 \\
4.5 \\
3.5\end{array}$ & $\begin{array}{l}361 \\
331 \\
315 \\
313 \\
251 \\
183\end{array}$ & $\begin{array}{l}8.0 \\
8.0 \\
7.8 \\
7.8 \\
6.0 \\
5.0\end{array}$ \\
\hline
\end{tabular}

* Oestrogen $=7.5 \mathrm{mg}$ oestradiol-17 $\beta$ Days 10 to 29 or 10 to $35 ; \mathrm{I}=25,100$ or $200 \mathrm{mg} /$ day of ICI 33828 from Days 20 to 29 or 20 to $35 ; P=150 \mathrm{mg}$ progesterone or $1000 \mathrm{mg} /$ day medroxyacetate progesterone Days 20 to 29 or 20 to 35 of the cycle.

acetate were given in the feed. One sow on each treatment was subjected to laparotomy between Days 8 and 12 and the CL in one ovary were marked with India ink. No accessory CL were formed in sows in any treatment group. On Day 30 or 36, the sows were killed. The CL were measured and weighed, and ovarian and stromal weights were recorded. The data were analysed by least squares analysis with preselected orthogonal comparisons. To determine the effect of ICI 33828 and progesterone as compared to the oestrogen treatment, a $t$-test was used on the pooled Day 30 and Day 36 means for mean CL weight and average GL diameter.

Treatment means and mean squares are presented in Tables 1 and 2 respectively. There was a significant treatment effect in the analysis of ovarian weight, mean CL weight and average CL diameter. The orthogonal comparisons showed that progesterone $(150 \mathrm{mg} /$ day $)$ and medroxyprogesterone 
acetate $(1000 \mathrm{mg} /$ day) caused a lower mean total cL weight and mean CL weight $(P<0.05)$, and ovarian weight and average cL diameter $(P<0.01)$ than that of sows treated with ICI 33828. Sows treated with ICI 33828 at $200 \mathrm{mg} /$ day had a lower $(P<0.05)$ mean stromal weight than sows treated with 25 and $100 \mathrm{mg} /$ day of ICI 33828. Comparison between the average of the ICI 33828 treatments with the oestrogen treatment, and of the average of the progesterone treatments with the oestrogen treatments, revealed that progesterone caused a lower average cL diameter and mean cL weight $(P<0.05)$ but ICI 33828 had no effect on these variables when compared to the oestrogen treatment. No other variables were compared for differences.

The results clearly indicate that progesterone causes a marked reduction in CL size and weight, whereas the ICI 33828 compound does not reduce cL size

TABLE 2

ANALYSIS OF VARIANCE OF VARIOUS OVARIAN GHARACTERISTICS AFTER TREATMENT WITH ICI 33828 OR PROGESTERONE IN SOWS WITH OESTROGEN-MAINTAINED GORPORA LUTEA

\begin{tabular}{|c|c|c|c|c|c|c|c|}
\hline \multirow{2}{*}{ Source } & \multicolumn{7}{|c|}{ Mean squares } \\
\hline & $d f$ & $\begin{array}{c}\text { Ovarian } \\
w t\end{array}$ & $\begin{array}{c}\text { Total } \\
C L \text { wt }\end{array}$ & $\stackrel{\text { No. }}{C L}$ & $\begin{array}{c}\text { Stromal } \\
w t\end{array}$ & $\begin{array}{l}\text { Mean } \\
C L \text { wt }\end{array}$ & $\begin{array}{c}\text { Ave. } C L \\
\text { dia. }\end{array}$ \\
\hline $\begin{array}{l}\text { Day } \\
\text { Treatment } \\
\text { D } \times T \\
\text { Within }\end{array}$ & $\begin{array}{r}1 \\
5 \\
5 \\
12\end{array}$ & $\begin{array}{c}6 \cdot 6 \\
21 \cdot 8^{*} \\
10 \cdot 8 \\
6 \cdot 2\end{array}$ & $\begin{array}{l}1 \cdot 1 \\
8 \cdot 8 \\
0 \cdot 5 \\
3 \cdot 1\end{array}$ & $\begin{array}{r}0.9 \\
38.4 \\
10.7 \\
20.7\end{array}$ & $\begin{array}{l}5 \cdot 3 \\
5 \cdot 7 \\
2 \cdot 5 \\
3 \cdot 9\end{array}$ & $\begin{array}{c}0.7 \\
17.5^{*} \\
1.2 \\
5.0\end{array}$ & $\begin{array}{l}0.8 \\
5 \cdot 3^{*} \\
0.8 \\
1.7\end{array}$ \\
\hline $\begin{array}{l}\text { Orthogonal comparisons } \uparrow \\
\text { Oestrogen versus Rest } \\
I_{\text {versus } P} \\
P_{150} \text { versus } P_{1000} \\
I_{25+100} \text { versus } I_{200} \\
I_{25} \text { versus } I_{100}\end{array}$ & $\begin{array}{l}1 \\
1 \\
1 \\
1 \\
1\end{array}$ & $\begin{array}{l}24 \cdot 1 \\
58 \cdot 8 * * \\
16 \cdot 6 \\
13.0 \\
1.6\end{array}$ & $\begin{array}{c}10 \cdot 4 \\
26 \cdot 3^{*} \\
4 \cdot 8 \\
2 \cdot 9 \\
0\end{array}$ & $\begin{array}{r}14.7 \\
100.1 \\
18.6 \\
64.7 \\
0.9\end{array}$ & $\begin{array}{c}4.2 \\
0.1 \\
1.8 \\
22 \cdot 0^{*} \\
0.7\end{array}$ & $\begin{array}{l}21 \cdot 8 \\
46 \cdot 4^{*} \\
16.5 \\
2.5 \\
0.2\end{array}$ & $\begin{array}{c}2 \cdot 5 \\
15 \cdot 9 * * \\
7 \cdot 2 \\
0 \cdot 7 \\
0 \cdot 3\end{array}$ \\
\hline
\end{tabular}

$* P<0.05, * * P<0.01$.

$\dagger I=25,100$ or $200 \mathrm{mg}$ ICI $33828 /$ day; $P=150$ or $1000 \mathrm{mg}$ progesterone/day.

and weight in oestrogen-treated sows. Benson \& Zagni (1965) have suggested that the ICI 33828 compound may increase prolactin secretion in the lactating rat by an inhibition of the prolactin-inhibiting factor. Therefore, antagonism of prolactin secretion by high levels of progesterone in the presence of exogenous oestrogen might account for the reduction in CL size and weight by progesterone. Progesterone, however, is thought to act in a positive feedback with prolactin (Rothchild, 1967). Both progesterone and ICI 33828 appear to block the LH surge late in the oestrous cycle (Garbers \& First, 1969a), and both probably have a major influence on the hypothalamus. The effects on appetite, however, are opposite (Harrington \& Linkenheimer, 1966; Rothchild, 1967). A tendency for ICI 33828 treatment to cause lower pituitary prolactin levels than progesterone treatment at Day 14 of the oestrous cycle in gilts has been reported, and may also indicate differential effects of the two compounds on prolactin release (Garbers \& First, 1969a). 
The reduction in GL size and weight caused by progesterone may, however, be attributed to direct effects on the GL, or indirectly via the uterus. Experiments using high levels of progesterone before oestrogen injection, or progesterone, oestrogen, hysterectomy combinations in an attempt to block a pituitary luteotrophin would help clarify the mechanism by which oestrogen effects maintenance of the GL in the pig.

Published with the approval of the Director of the Wisconsin Agricultural Experiment Station, Madison. Paper Number 537 from the Department of Meat and Animal Science. This study was supported in part by Ayerst Laboratories, New York.

\section{REFERENCES}

Anderson, L. L., Dyck, G. W., Mori, H., Henricks, D. M. \& Melampy, R. M. (1967) Ovarian function in pigs following hypophysial stalk transection or hypophysectomy. Am. J. Physiol. 212, 1188 .

Benson, G. K. \& ZaGni, P. H. (1965) The effects of 1- $\alpha$-methylallylthiocarbamoyl-2-methylthiocarbamoyl hydrazine (ICI 33828) on lactation in the rat. F. Endocr. 32, 275.

Brinkley, H. J., Norton, H. W. \& Nalbandov, A. V. (1964) Is ovulation alone sufficient to cause formation of corpora lutea? Endocrinology, 74, 14.

Du Buisson, F. du Mesnil, Leglise, P. C., Anderson, L. L. \& Rombauts, P. (1964) Maintien des corps jaunes et de la gestation de la truie au cours de la phase preimplantoire après hypoph ysectomie. Proc. Vth int. Cong. Anim. Reprod., Trento, p. 571.

Garbers, D. L. \& FIrst, N. L. (1969a) The effects of injected oestradiol-17 $\beta$, progesterone and dietary ICI 33828 on ovarian and pituitary functions in the sow and gilt. $\mathcal{F}$. Reprod. Fert. (in press).

Garbers, D. L. \& First, N. L. (1969b) A block of the luteinizing hormone and of ovulation despite oestrus in ICI 33828 treated gilts. 7. Reprod. Fert. (in press).

Gardner, M. L., First, N. L. \& Gasida, L. E. (1963) Effect of exogenous estrogens on corpus luteum maintenance in gilts. F. Anim. Sci. 22, 132.

Hammond, J., JR \& Robson, J. M. (1951) Local maintenance of the rabbit corpus luteum with oestrogen. Endocrinology, 49, 384.

Harrington, F. E. \& Linkenheimer, W. H. (1966) The influence of the route of administration of 1-alpha-methylallylthiocarbamoyl-2-methylthiocarbamoylhydrazine on reproduction in rats and mice. 7. Reprod. Fert. 11, 73.

Nishrkawa, Y. (1959) Studies on reproduction in horses. Japan Racing Association. Shiba Tamuracho Minatoku, Tokyo.

Piper, E. L. \& Foote, W. C. (1968) Ovulation and corpus luteum maintenance in ewes treated with $17 \beta$-oestradiol. 7. Reprod. Fert. 16, 253.

Polge, C. \& DAy, B. N. (1969) Induction of estrus and ovulation in swine during pituitary suppression with methallibure. 7. Anim. Sci. 28, 73.

Rothchild, I. (1966) The nature of the luteotrophic process. F. Reprod. Fert. Suppl. 1, 49.

Rotнchild, I. (1967) The neurologic basis for the anovulation of the luteal phase, lactation and pregnancy. In: Reproduction in the Female Mammal, p. 30. Eds. G. E. Lamming and E. C. Amorosso. Plenum Press, New York.

Wagner, J. F. \& Veenhuizen, E. L. (1965) Effect of estrogens and CAP on ovarian function in the gilt. (Abstract). 7. Anim. Sci. 24, 932. 